\title{
A CASE STUDY IN THE MOLDAVIAN CENTRAL PLATEAU, ROMANIA - HABITAT DISTRIBUTION, CONSERVATION STATUS AND HUMAN IMPACT IN A PROTECTED AREA
}

\author{
Ilie-Adrian STOICA ${ }^{1}$, Sorina FARCAŞ⿻ ${ }^{1}$, Tudor Mihai URSU ${ }^{1}$, Bogdan Iuliu HURDU ${ }^{1}$, Pavel Dan \\ TURTUREANU ${ }^{2}$, Mihai PUŞCAŞ ${ }^{2,3}$, Adrian OPREA ${ }^{4}$, Marian PROOROCU $^{5}$ \\ ${ }^{1}$ National Institute of Research and Development for Biological Sciences, Institute of Biological Research Cluj, \\ 48 Republicii str., RO-400015 Cluj-Napoca, Romania \\ ${ }^{2}$ Babeş-Bolyai University, Botanical Garden Al. Borza, 42 Republicii str., RO-400015 Cluj-Napoca, Romania \\ ${ }^{3}$ Babeş-Bolyai University, Department of Taxonomy and Ecology, Faculty of Biology and Geology, \\ 42 Republicii str., RO-400015 Cluj-Napoca, Romania \\ ${ }^{4}$ University “Alexandru Ioan Cuza”, Botanical Garden, 7-9 Dumbrava Roşie str., RO-700487 Iaşi, Romania \\ ${ }^{5}$ University of Agricultural Sciences and Veterinary Medicine Cluj-Napoca, Faculty of Agriculture, 3-5 Calea \\ Mănăştur, RO-400372 Cluj-Napoca, Romania \\ e-mail: sorina.farcas@icbcluj.ro
}

\begin{abstract}
The paper presents the results of the studies performed in the Natura 2000 site Pădurea BârnovaRepedea (ROSCI0135), in order to identify and map habitat types and plant species of community interest. Palynological and archaeo-botanical studies in the region were reviewed, in order to assess the presence of the ancient forests. This protected area was designed to preserve forests from two habitats types of community interest, namely Asperulo-Fagetum beech forests and Dacian oak-hornbeam forests, and to shelter a species of wild and endangered orchid, Cypripedium calceolus L. During the field work other Natura 2000 habitats of community interest have been identified: mountain hay meadows, Ponto-Sarmatic steppes and Ponto-Sarmatic deciduous thickets. The information obtained provided new data on the habitats and plant species distribution. Field data were correlated with existing topographic maps and aerial photography. The use of the Geographic Information System allowed translating the field distribution of the species and habitat types into accurate maps, which can be used in the future by the managers of this site for implementing adaptive conservation measures. The human activities with potential impact on this Natura 2000 site have been recorded. The map of current pressures on the site was generated based on these impact categories.
\end{abstract}

Keywords: Pădurea Bârnova-Repedea SCI, Natura 2000 ecological network, mapping, Cypripedium calceolus, Romanian habitat classification system, vegetation history

\section{Introduction}

The Natura 2000 European ecological network includes Special Protected Areas (SPAs) classified under the Birds Directive [51] and Sites of Community Importance (SCIs) under the Habitats Directive [49], both designed for the conservation of species and habitats of community interest. Their protection and conservation in Romania is guaranteed by the Government Emergency Ordinance no. 57/2007 [53], approved by the Law 49/2011 [55], which transposes into national law the EU Council Directive 92/43/EEC on the conservation of natural habitats and wild fauna and flora [50]. With the implementation of the Habitats Directive, EU member states committed themselves to protect a range of highly threatened habitats within their territory. 
Monitoring and reporting on the status of the Natura 2000 habitats is an essential part of an effective conservation, and an important obligation under the Habitats Directive. Every six years, member states have to report on the actual area, range, quality and future prospects, considering human activities for each habitat type [42].

In order to meet these requirements the Geographic Information System (GIS) is used worldwide. It allows the accurate map positioning of the species, habitats and human impact that is translating their spatial distribution from the field. These data may be used in the future by the managers of each site for implementing adaptive conservation measures to preserve biodiversity and the cultural heritage that are strongly connected $[47,44]$.

The Natura 2000 Barometer of December 2013, which monitors progress in the implementation of both the Habitats and the Birds Directives [57], provides the following information as regards the SCIs and the SPAs in Romania, that cover together $22.56 \%$ of the national territory:

- $\quad 383$ SCIs, having a total surface of $41.468,65 \mathrm{~km}^{2}$, cca. $16.68 \%$ of the national territory;

- 148 SPAs, having a total surface of $36.977,72 \mathrm{~km}^{2}$, cca. $14.83 \%$ of the national territory.

The species and habitats for which these 531 protected areas were designed require rigorous and actual scientific documentation of their spatial distribution, conservation status and future perspectives within each Natura 2000 site from Romania. In this context, the overarching goal of this study is to contribute to the efficacy of the Romanian Natura 2000 network in conserving biodiversity at the site ROSCI0135 Pădurea Bârnova-Repedea. Specifically, the research objectives are: (1) to document and map the spatial distribution of the plant species and habitat types enlisted in the Natura 2000 Standard Data Form of this site; (2) to register and map the potential human impact on the protected area.

\section{Material and Methods}

Study site

The limits for the Natura 2000 site ROSCI0135 Pădurea Bârnova-Repedea $\left(47^{\circ} 1^{\prime} 27^{\prime \prime} \mathrm{N}\right.$, $27^{\circ} 38^{\prime} 50^{\prime \prime} \mathrm{E}$ ) have been drawn in conformity with the Order of the Minister for Environment and Forests no. 2387/2011 [56] on an area of 12216 ha; the elevation within the site varies between 103 and $419 \mathrm{~m}$ a.s.1. (Fig. 1). The climate is characterized by an annual average temperature of $9.5^{\circ} \mathrm{C}$ and a yearly average rainfall of $585 \mathrm{~mm}$.

The site partially overlaps with ROSPA0092 Pădurea Bârnova protected area. Within the limits of the SCI, several nature reserves of national interest can be found: Locul fosilifer Dealul Repedea, of geological-paleontological type; Pietrosu-Dobrovăţ, of forest type; PoieniCărbunăriei, of forest type; and Poiana cu Schit, of botanical type (Fig. 1). All these are included in the Law No. 5/2000 - Section III - Protected Areas [54]. Details of the protected areas within the Natura 2000 site are found in some papers [35, 22, 39, 31]. Previous studies carried out in this region have focused on flora and vegetation synthesis $[26,27,46]$, but the current aspects regarding the Natura 2000 habitat types and the conservation issues from this site have not been approached.

The Natura 2000 site ROSCI0135 Pădurea Bârnova-Repedea has been declared for two 
habitat types of community interest: 9130 Asperulo-Fagetum beech forests and 91Y0 Dacian oak-hornbeam forests. The general description of these habitat types is provided in the Natura 2000 interpretation manuals [52, 28, 30]. According to the Standard Data Form, the habitats of community interest in the Natura 2000 site Pădurea Bârnova-Repedea cover 33\% (9130) and respectively $55 \%$ (91Y0) from the total surface of the site. These preliminary data on habitat areas were verified in the field, to correct any inconsistencies. The presence of the community interest orchid Cypripedium calceolus within the site has also been investigated. Moreover, the sources of human impact were recorded, in order to provide information necessary for biodiversity conservation in this site.

\section{Data collecting and analysis}

In order to evaluate the conservation status of species and habitats in this site, in the context of human impact, field surveys were carried out in the year 2012. The Braun-Blanquet [14] method was used for investigating phytocoenoses in the field, combined with the work technique of "itinerary" investigations. The succession of the research phases was as follows:

(1) analytical phase, aiming to identify the qualitative, quantitative and spatial structure of phytocoenosis and habitats, their distribution and spatial extent, along with the intensity of anthropic pressure;

(2) synthetic phase, consisting in analysing the fragments of phytocoenoses in order to assign them to vegetation units (coenotaxonomic units/ habitat types).

Relevés were collected from "key points", along pre-established transects within the Natura 2000 site, in the optimal period for each phytocoenosis type. Transects have focused on the two types of community interest habitats. In order to select transects, several stages have been followed. The existing topographical data (aerial photography 1:5000, topographical maps 1:25000 and 1:50000), as well as polygons with the limits of the Natura 2000 site and nature reserves have been loaded in the Garmin CS60 GPS units. The correlation of all existing data (topographical data, aerial photography, and the Standard Data Form) has allowed drawing optimal transects for the study of habitats of community interest from the site. For Cypripedium calceolus investigation, transects have taken into account the ecological requirements of this rare and endangered species [2].

A qualitative and quantitative assessment of the habitats of community interest has been performed, based on information regarding their floristic structure. Habitats which were not mentioned within the Standard Data Form have also been recorded. Conservation status of habitats and plant species of community interest has been assessed. For each habitat type, the distribution was represented as polygon. The identification and mapping of habitats from the site was made at a scale of 1:10000.

In order to identify the major sources of potential human impact on habitats, aerial photographs were used (with $0.5 \mathrm{~m}$ pixel resolution), as well as topographical maps at different scales (1:5000, 1:25000, 1:50000). These impact sources have been digitized to a point shapefile, both from the area of the Natura 2000 site, as well as from neighbouring areas, within a $5 \mathrm{~km}$ radius around the site. Six different distance classes from the site boundaries, between 500 and $5000 \mathrm{~m}$, have been taken into consideration, in order to reflect the gradual spatial distribution of the most important factors of human impact.

In order to evaluate the real human impact on the protected area, field observations 
focused on identification and inventory of impact sources (according to Article 17: code list of threats and pressures of the Habitats Directive, 2006) but also on detection and assessment of the degree of damage to habitats and species. Present-day impacts and potential threats have been analysed for each habitat type of community interest and for Cypripedium calceolus within the Natura 2000 site, in order to establish the conservation measures.

The delimitation method used both GPS field measurements and the physicogeographical, geomorphological elements of the landscape and ecosystems followed by analysis and processing in ArcGIS software. The coordinate systems used for the maps projection was the Romanian National Coordinate System: Stereo 1970.

Several palynological and archaeobotanical studies were reviewed, in order to assess the status of the ancient forests in the region.

\section{Results}

The study of palynological and archaeo-botanical data from 17 sites in Moldova, in the territory of Iaşi and the neighbouring counties of Neamţ, Bacău, Suceava and Botoşani revealed the presence of more or less extensive forests in the studied region, from ancient times.

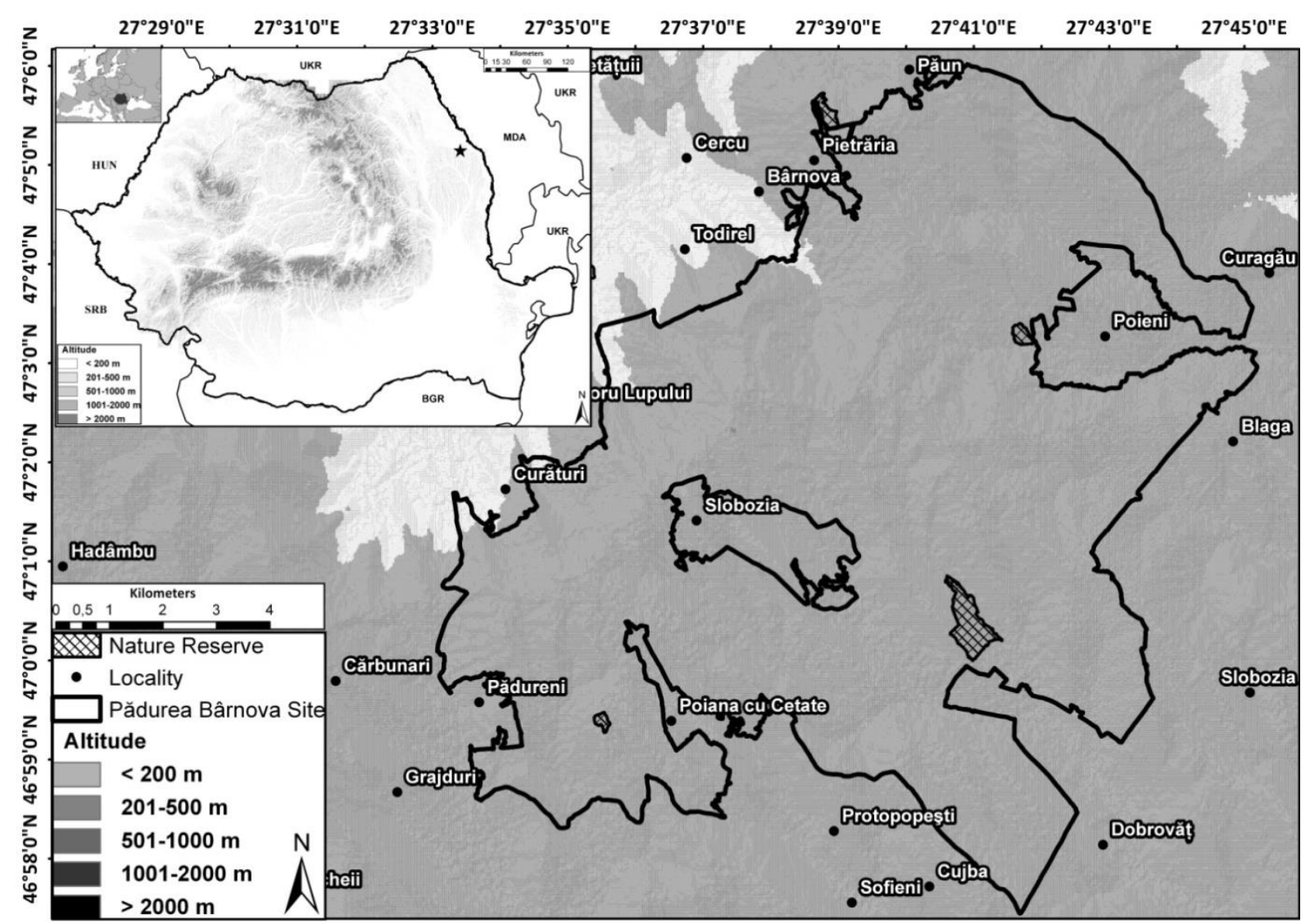

Fig. 1: The boundary of the Pădurea Bârnova-Repedea Natura 2000 site

During field studies in the Natura 2000 site Pădurea Bârnova-Repedea, the distribution of the habitats from the Standard Data Form (9130 and 91Y0) has been established. Apart from these types, other habitat types of community/priority interest were mapped in the investigated Natura 2000 site: 6520 Mountain hay meadows, 62C0* Ponto-Sarmatic steppes and 40C0* 
Ponto-Sarmatic deciduous thickets. The information obtained has been used in the laboratory to generate the distribution map for all habitats (of community interest and other types) identified in the site (Fig. 2).

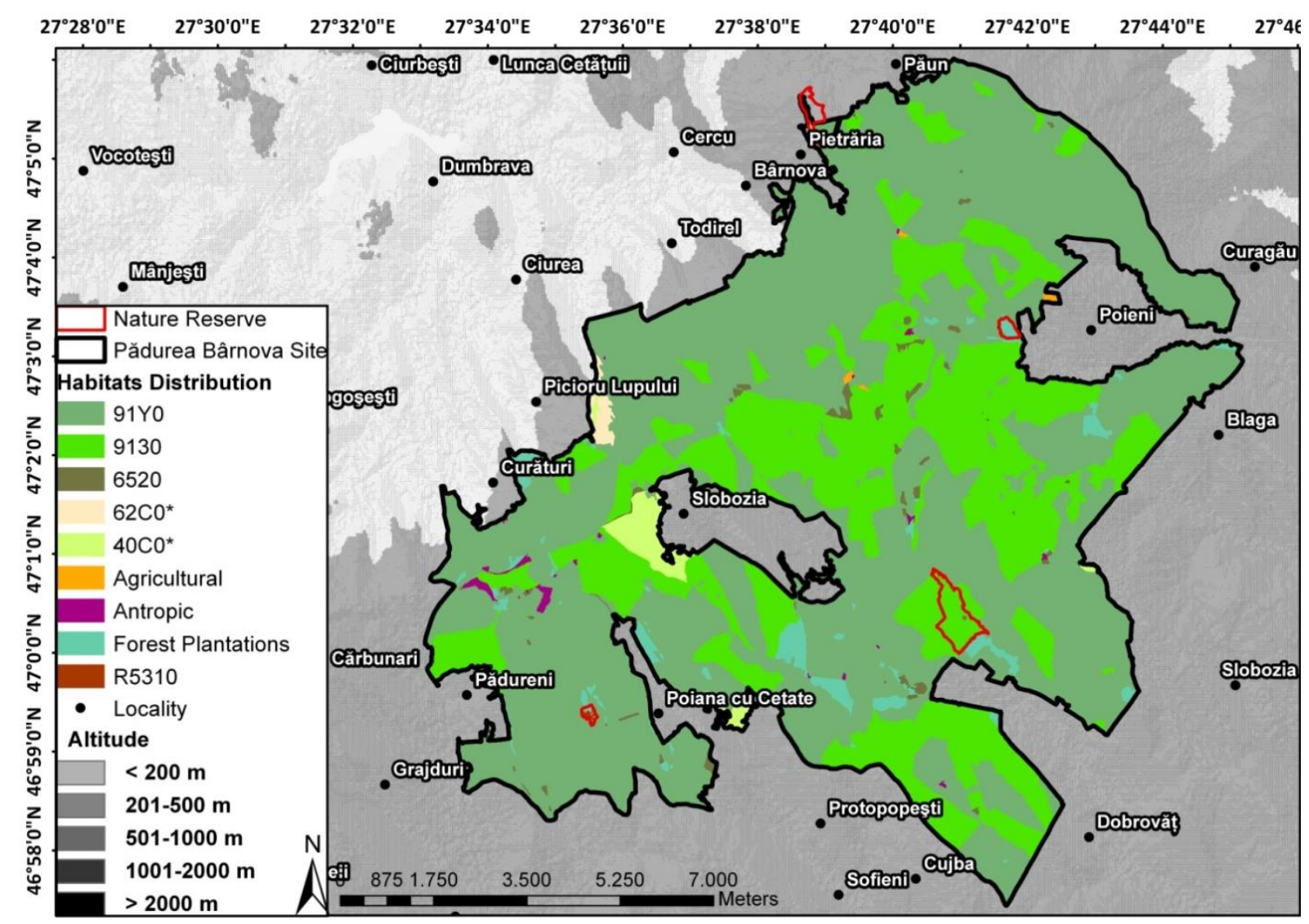

Fig. 2: Habitat types distribution in the Pădurea Bârnova-Repedea Natura 2000 site.

Digitizing the vegetation polygons in ArcGIS [29] allowed us to calculate the surfaces covered by each habitat type (Tab. 1). The dominant habitat type within the site is 91Y0 Dacian oak-hornbeam forests, covering 8137.19 ha $(66.61 \%$ of the entire surface of the SCI) and distributed in a non-uniform manner.

The map of current pressures, based on the impact categories, is presented in Fig. 3. Several sources of human impact have been identified within the site and in the 5-km buffer zone: 22 sheepfolds, 28 stables, 4 cottages, 6 forestry cottages, 22 farms (livestock farms, vineyards, orchards, and fisheries), 2 hunting lodges, 2 monasteries and 42 villages. Within the site there have also been identified 168 road sections (including two national roads), totaling 137 $\mathrm{km}$ in length, and railways (Iaşi-Bucharest), relevant in terms of impacts on habitats and species of community interest.

\section{Discussion}

The history of forests in the region

The paleobotanical, palynological, anthracological, and carpological analyses performed both in palynological and archaeological sites, demonstrate the millennial age of forests in the site area, but also at regional level [43]. 
Table 1: Habitat types and their current areas in the Pădurea Bârnova-Repedea Natura 2000 site

\begin{tabular}{ccc}
\hline Habitat type & Area (ha) & Percentage in the Natura 2000 site (\%) \\
\hline 91 Y0 & 8137.19 & 66.61 \\
9130 & 3468.05 & 28.39 \\
Plantation & 266.25 & 2.17 \\
$40 \mathrm{C} 0^{*}$ & 167.66 & 1.37 \\
6520 & 82.28 & 0.67 \\
$62 \mathrm{C} 0^{*}$ & 44.07 & 0.36 \\
Anthropic & 35.37 & 0.28 \\
Agricultural & 11.26 & 0.09 \\
Other & 0.52 & 0.04 \\
R5310 & 3.30 & 0.02 \\
\hline
\end{tabular}

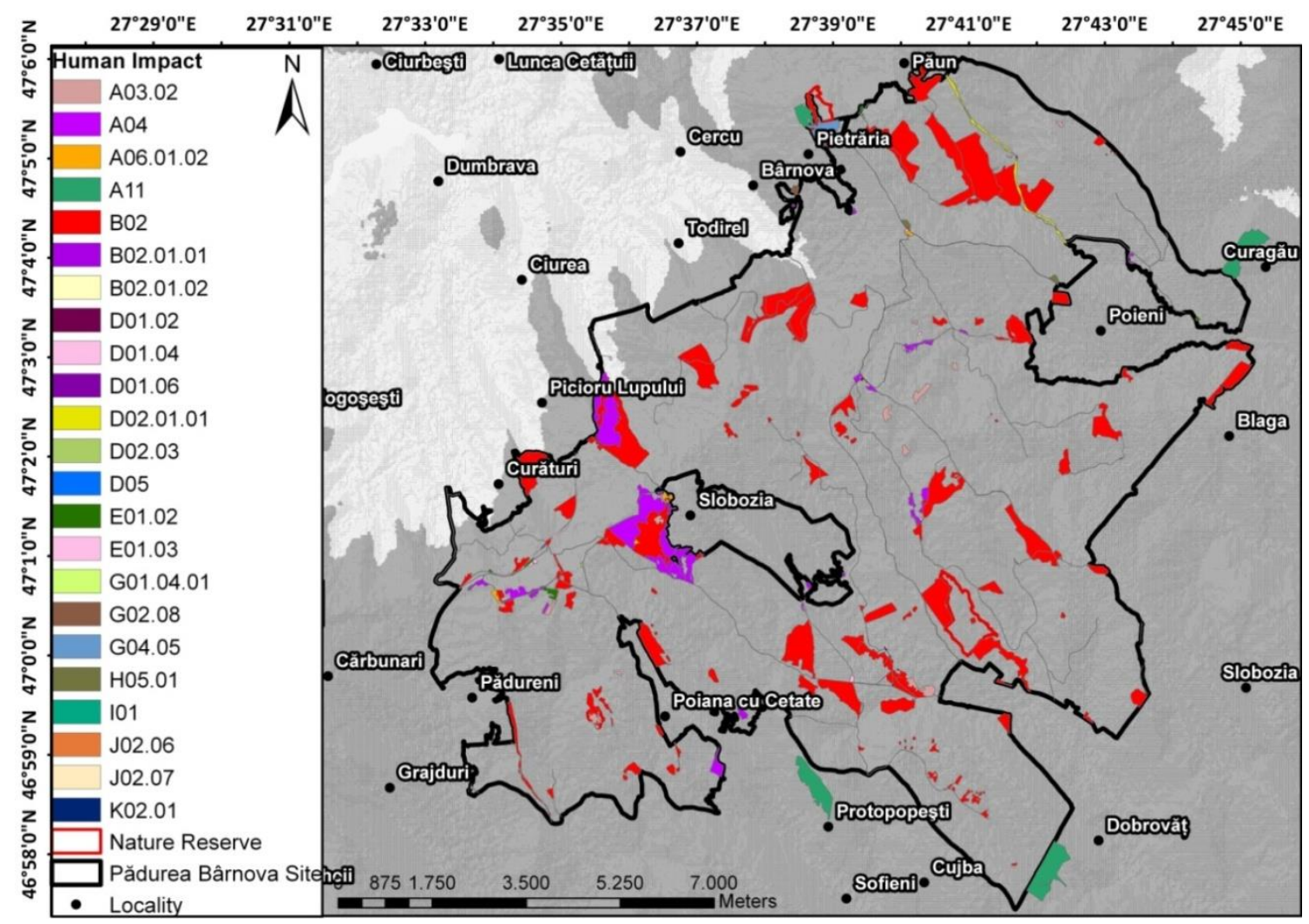

Fig. 3: Distribution of current pressures in the Pădurea Bârnova-Repedea Natura 2000 site

At the Neolithic archaeological site Isaiia-Balta Popii [6], the significant percentages of arboreal pollen grains, such as Fagus, Quercus, Ulmus, and Tilia, indicate the presence of a nearby forest. At Costeşti [4, 8] the authors state that some deciduous trees such as Tilia and Quercus were present not far from this chalcolithic site assigned to Cucuteni culture. Also, Quercus, Tilia and Corylus were certainly present during the Middle Holocene at the chalcolithic (aeneolithic) site Hoiseşti, in the proximity of the archaeological site [3]. At the tardenoisian site Erbiceni [17, 18, 19], the existence of deciduous trees (Ulmus and Quercus) was demonstrated 
since the Alleröd climatic oscillation [19]. ${ }^{14} \mathrm{C}$ dating of $7.850 \pm 215$ B.P. confirms the continuity of the deciduous forest around this site. Older anthracological analyses in this settlement also demonstrated based on macrofossils, the existence of Quercus and Tilia [17]. At Topile - Dealul Catargii [20] the authors estimate that here the habitation can be assigned to the mild climatic oscillations Laugerie - Lascaux, at the termination of the Last Glacial Maximum [25]. Pollen analyses conducted at the site revealed the presence of Pinus, Betula, Salix, Picea, Tilia, Ulmus and Carpinus.

South of the Natura 2000 site Pădurea Bârnova-Repedea, in the archaeological site of Poduri - Dealul Ghindari (chalcolithic site assigned to Cucuteni culture), Monah \& Monah $[37,38]$ identified foliar impressions of Corylus avellana and Tilia plathyphyllos s. lato, belonging to the Precucuteni culture. The same authors stated in the table regarding the Flora of Eneolithic/Cucuteni culture from western Moldavia the existence of Acer, Alnus, Castanea, Fagus, Fraxinus, Juglans, Quercus, and Salix. More recently, Bodi et al. [7] detailed the results of palynological analyses performed in this archaeological site, certifying the presence of deciduous tree pollen (Quercus, Tilia, Carpinus, Salix, Fraxinus, Corylus).

There is also evidence of old deciduous forests from the sites of Pângărăcior [11], Râpa lui Bodai from Târpeşti [17, 24, 34], Hălăbutoaia - Ţolici [23, 24], Ponoare-Bosanci [12], Bahna valley near the villages Dersca and Lozna [10, 13], Lunca Zamostei [36], and Feteşti Adâncata commune [9]. Pollen analyses also certify the early presence of the forests in the sites Suliţa - Drăcşani [41], Drăguşeni [17], Mitoc-Valea Izvorului [5, 19] and Ripiceni Izvor [16, 19].

\section{Present-day vegetation within the Natura 2000 site Pădurea Bârnova-Repedea}

The main features of the habitats of community interest, identified in the Pădurea Bârnova-Repedea Natura 2000 site as a result of field studies, as well as the issues related to their conservation status and human impact, are presented below.

\section{Asperulo-Fagetum beech forests}

The habitat of medio-European and Atlantic areas of Western, Central, and Central Nordic Europe [30], has a natural origin in the site. It includes three types of habitats in the Romanian classification system, according to Doniţă et al. [28]: R4118 Dacian forests of beech (Fagus sylvatica) and hornbeam (Carpinus betulus) with Dentaria bulbifera; R4119 Dacian forests of beech (Fagus sylvatica) and hornbeam (Carpinus betulus) with Carex pilosa; R4120 Moldavian mixed forests of beech (Fagus sylvatica) and silver lime (Tilia tomentosa) with Carex brevicollis. Forest associations characteristic to this habitat type are: Carpino-Fagetum Paucă 1941 subass. tilietosum tomentosae Mititelu et al. 1977; Galio schultesii-Fagetum Burduja et al. 1973, Chifu et Ştefan 1994; Lathyro veneti-Fagetum (Dobrescu et Kovács 1973) Chifu 1995 [28, 30].

Its distribution within the site is mostly related to environmental conditions. In terms of topography, it usually occupies the areas from the hilltops - over 300-350 m a.s.1. Nevertheless, one factor that should be taken into account is forest management, the potential distribution of this beech-dominated habitat most likely being wider in the past. This assumption is based on the frequent presence of very old beech individuals within stands of younger trees from other species. These old specimens are considered as remnants of former beech forests. In time, 
through the replacement of tree species, in this case of beech by lime and hornbeam, the areas occupied by the habitat 9130 have diminished. On the contrary, the species composition of the herb layer did not change significantly within this relatively small timespan, of 50-100 years.

\section{Y0 Dacian oak-hornbeam forests}

The habitat 91Y0 is the best represented within the site, making up most of the forested area. Similarly to the previous one, it is related to the particular environmental conditions. It includes two types of habitats in the Romanian classification system [28]:

1. R4125 Moldavian forests with sessile oak (Quercus petraea), beech (Fagus sylvatica), lime (Tilia cordata) with Carex pilosa. This habitat can be found on southern and western aspects and even on northern ones at lower altitude, below $350 \mathrm{~m}$ a.s.1., having a more thermophillous character. Its wide distribution within the site is explained by the more continental climate, specific to the Central Moldavian Plateau. In contrast to habitat 9130, this habitat is less fragmented.

2. R4143 Dacian forests of oak (Quercus robur) with Melampyrum bihariense are usually found on plateaus near large valleys - probably former river terraces. On large sized plateaus, stagnation of rain water occurs frequently, especially in spring, providing mesophillous and sometimes meso-hygrophillous conditions, favourable to this type of habitat. This habitat occupies a wide area in the western part of the site. Most probably, in the past, the forests of Quercus robur and Carpinus betulus occupied larger areas, currently their surface being on the decrease, because of timber extraction practices that have caused the fragmentation of these communities. However, evidence of natural regeneration and reforestation activities has been observed.

\section{Mountain hay meadows}

This comprises the large meadows of the site (Festuco rubrae - Agrostietum capillaris Horvat 1951) that are established in forest clearings and provide fodder for game animals. Therefore, the habitat has a scattered distribution, surrounded by forests. In summer the meadows are mowed once or twice for hay production. This habitat is important mainly for its ecosystem services.

\section{C0* Ponto-Sarmatic steppes}

This habitat is present within the site in very small areas, mainly in the natural reserve Locul fosilifer Dealul Repedea, of geological and paleontological type. The habitat is represented by xero-mesophillous communities of Festuca rupicola and Festuca valesiaca (syntaxon Taraxaco serotinae - Festucetum valesiacae Burduja et al. 1956), specific for sunny areas with low humidity.

\section{C0* Ponto-Sarmatic deciduous thickets}

It is a priority habitat of sub-thermophyllous bushes that occupies small areas on hillsides with various slopes, at forest edges, most often with a patchy distribution. This habitat type appears after abandonment of pastures and represents a successional stage towards climax forests within this area.

The rare and endangered orchid Cypripedium calceolus (Lady's Slipper Orchid) was identified in four small areas. In terms of habitat requirements, the species is mesophilous, micro-mesotherm, acidophillous-neutrophillous, helio-sciadophile and calcicole [33, 21]. It grows in shady forests and scrub of sessile oak, up to the boreal belt of the spruce, blooming in 
May-June [21]. In Europe, this species has become increasingly rare, having small populations throughout its geographical distribution area, being protected in many countries [15, 45]. Although individuals are long-lived, sometimes up to 60-100 years [32], extinction analysis revealed that in a population of around 20 individuals (as is the case of many European sites), survival chances significantly decrease if more than two shoots are collected over a period of five years $[48,1]$.

According to Nicolè et al. [40], many orchids, including Cypripedium, exhibit dormancy in some years, under unfavorable conditions, which further reduces their chance of survival. Since blooming occurs in cycles that sometimes encompass more years, the monitoring process for this orchid requires long-term studies.

In all four points where the species is present within the Natura 2000 site ROSCI0135 Pădurea Bârnova-Repedea, only a few individuals bear flowers. This is a common situation for this species, caused not only by environmental conditions (especially soil), but also due to the physiological characteristics of the species [40]. The species occurs in scattered populations in the site, on calcareous, neutrophyllous soils (rendzinas), on humus-rich substrates. It prefers sheltered stations with a relatively thick layer of litter, vegetating under various degrees of canopy closure $65-90 \%$. Tree species composition of forests in the four stations is quite diverse, the most frequent being Quercus petraea, Fagus sylvatica, Prunus avium, Tilia cordata, Corylus avellana. The herb layer is dominated by mull humus flora, such as Asarum europaeum, Circaea lutetiana and Lamiastrum galeobdolon.

\section{Conservation Status and Human Impact within the Natura 2000 site Pădurea Bârnova-} Repedea

The structure and functions of the habitats 9130 and 91Y0, including typical species, are in good condition, without significant deterioration. Some actions of timber extraction of beech and hornbeam were observed in the field across the 9130 habitat, but there are not major violations to seriously worsen habitat conservation status. The appearance of this type of habitat only in certain areas of the site is almost entirely due to environmental conditions and in very few cases to silvicultural interventions. Referring to the habitat 91Y0, which occupies the largest part of the site, no actions significantly affecting the conservation status were observed, except those which were performed according to forest management. An exception is represented by oak and hornbeam forests with Melampyrum bihariense and exceptionally Euonymus nanus in the western part of the site, which have suffered considerable losses, but still in relatively small proportion compared with the extent of this type of habitat at the site.

Considering the current pressures in the Natura 2000 site Pădurea Bârnova-Repedea, the presence of some large categories can be observed, such as: A - Agriculture, B - Silviculture, D Communication networks, E - Urbanisation, residential and commercial development, F - Use of biological resources other than agriculture and forestry, $\mathrm{G}$ - Intrusions and human imbalances, $\mathrm{H}$ - Pollution, I - Invasive species, other problems of species, J - Changes in the natural system, K - Natural biotic and abiotic processes (without catastrophes), M - Global Change. Considering the categories of human impact identified, non-intervention management is recommended for semi-natural habitats, like 9130 and $91 \mathrm{Y} 0$, and surrounding areas with self-restoration capacity. Where replanting is necessary, non-native trees must be avoided in order to maintain the characteristic structure of these forest habitats. Generally, it is known that non-intervention 
management of protected areas and large Natura 2000 sites significantly improves habitat conservation status and living conditions for species depending on natural dynamic processes (e.g., all primary forest habitats in Central Europe).

\section{Conclusions}

Besides the two forest habitats enlisted in the standard data form of the site, three more community interest habitats were mapped. Asperulo-Fagetum beech forests have a fragmented distribution in the site, being influenced by both natural and human factors, which have reduced their distribution area within the site. Dacian oak-hornbeam forests are represented within the site by two habitat types (based on the Romanian classification system): Moldavian forests with sessile oak, beech, and lime that are widespread and have a continuous distribution in the site, while Dacian forests of oak have a fragmented distribution, being the most impacted habitat within the site. Cypripedium calceolus was recorded at only four isolated points within the site, with a small number of shoots. Sixty-one human impact types have been identified, representing current pressures on the site. In spite of these, the conservation status of the habitats is favourable. The GIS spatial distribution database and the generated maps are useful for designing the management plan of this site and serve to bring in agreement the conservation measures with the forestry management plans, in order to ensure the sustainability of economic activities within this area. The review of palynological and archaeobotanical results from several sites in Moldova revealed the presence of more or less extensive forests from ancient times.

Acknowledgements: This research was supported by Sectoral Operational Programme, Environment Axis 4, Ministry of the Environment and Climate Change, the National Agency for Environmental Protection, SINCRON Project.

\section{REFERENCES}

1. Antonelli, A., Dahlberg, C.J., Carlgren, K.H.I., Appelqvist, T., 2009, Pollination of the Lady's slipper orchid (Cypripedium calceolus) in Scandinavia, Nordic Journal of Botany, 27 (1-8): 266-273.

2. Balázs, Z.R., Roman, A., Balazs, H.E., Căpraş, D., Podar, D., 2016, Rediscovery of Cypripedium calceolus L. in the vicinity of Cluj-Napoca (Romania) after 80 years, Contribuţii Botanice, LI: 43-53.

3. Bejenaru, L., Bodi, G., Stanc, S., Danu, M., 2014, Middle Holocene landscape to the east of Carpathians: bioarchaeological considerations on the Chalcolithic site of Hoisești (Iași County, Romania), Carpathian Journal of Earth and Environmental Sciences, 9 (4): 121-128.

4. Bejenaru, L., Danu, M., Stanc, S., 2016, Overall evaluation of biological remains discovered in the Chalcolithic site (Cucuteni Culture, $\mathrm{V}^{\text {th }}-\mathrm{IV}^{\text {th }}$ Millennia cal B.C.) of Costeşti (Iaşi County, Romania), International Journal of Conservation Science, 7 (1): 93-100.

5. Bitiri, M., Cârciumaru, M., Vasilescu, P., 1978, Paleoliticul de la Mitoc-Valea Izvorului. Specificul culturii şi mediul natural, Hierasus, I: 33-41.

6. Bodi, G., Cavaleriu, R., Danu, M., Pîrnău, R., 2010, Preliminary considerations regarding the paleoenvironment in the hinterland of the Neolithic habitation-sites at Isaiia-Balta Popii and Hoiseşti-La Pod, Transylvanian Review XIX, Supplement No. 5 (1): 31-48.

7. Bodi, G., Pîrnău, R., Danu, M., Cavaleriu, R., 2013, Cercetări interdisciplinare în Neo-Eneoliticul din NordEstul României. Scripta archaeologica et historica Dacoromaniae Redigit Victor Spinei VI, Institutul de Arheologie Iaşi, Editura Universităţii “Alexandru Ioan Cuza”.

8. Boghian, D., Enea, S.C., Ignătescu, S., Bejenaru, L., Stanc, S.M., 2014, Comunităţile cucuteniene din zona 
Târgului Frumos. Cercetări interdisciplinare în siturile Costeşti şi Giurgeşti, Editura Universităţii „Alexandru Ioan Cuza”.

9. Boghian, D., Niculica, B.P., Oprea-Gancevici, D., Budui, V., 2013, Habitatul uman şi impactul antropic asupra mediului natural în protoistoria microzonei municipiului Suceava şi proximitaţi, În: Peregrinari Arheologice între Estul şi Vestul Europei, Studii în onoarea lui Tiberius Bader la aniversarea de 75 de ani, Studii şi Comunicări Satu Mare, Seria Arheologie, Editura Muzeul Judeţean Satu Mare, Editura Argonaut, Cluj Napoca, XXIX (1): 221-253.

10. Boşcaiu, N., Lupşa, V., 1982a, Analyse sporo-pollinique de la tourbe eutrophe de la vallée de Bahna près des villages Dersca et Lozna /distr. Suceava/, In: Paleobotany-palynology symposium, Cluj-Napoca, Facultatea de Biologie-Geografie-Geologie, Catedra de geologie-mineralogie, 103-105.

11. Boşcaiu, N., Lupşa, V., Ichim, I., 1976, Analiza sporopolinică a sedimentelor din mlaştina Pîngărăcior, Anuarul Muzeului Ştiinţe Naturale Piatra Neamţ, seria Geologie-Geografie, 3: 367-378.

12. Boşcaiu, N., Lupşa, V., Seghedin, T. S., 1981, Analize sporo-polinice in rezervaţia de la Ponoare-Bosanci /jud. Suceava/ şi consideraţii asupra istoriei carpenului în aria carpato-danubiană, Studii Comunicări Ocrotirea Naturii, Suceava, 5: 338-352.

13. Boşcaiu, N., Lupşa, V., Seghedin, T. G., 1982b, Evoluţia făgetelor la răsărit de Carpaţi (L'évolution des hêtraies à l'est des Carpates), In: Făgetele carpatine. Semnificaţia lor bioistorică şi ecoprotectivă. ClujNapoca, Academia R. S. România, Filiala Cluj-Napoca, Subcomisia ocrotirii monumentelor naturii, 81-90.

14. Braun-Blanquet, J., 1964, Pflanzensoziologie. Grundzüge der Vegetationskunde, Springer Verlag, Wien.

15. Butnariu, M., Samfira, I., 2013, Lady's Slipper Orchid (Cypripedium calceolus), Journal of Biodiversity \& Endangered Species, 1:e107. doi:10.4172/2332-2543.1000e107.

16. Cârciumaru, M., 1986, Valence chronologiques de la palynologie-confirmations dans les couches paléolithiques de Roumanie, Acta Interdisciplinaria, Nitra, IV: 175-180.

17. Cârciumaru, M., 1996, Paleoetnobotanica, Studii în Preistoria şi Protoistoria României (Agricultura preistorică şi protoistorică a României), Editura Glasul Bucovinei, Helios, Iaşi.

18. Cârciumaru, M., 2006, Paleoliticul, Epipaleoliticul şi Mezoliticul lumii, Editura Cetatea de Scaun Târgovişte.

19. Cârciumaru, M., Anghelinu, M., Niţu, E.-C., Cosac, M., Murătoreanu, G., 2007, Geo-Archéologie du Paléolithique Moyen, Paléolithique Supérieur, Epipaléolithique et Mésolithique en Roumanie, Editura Cetatea de Scaun, s.c. Editura Logos s.r.l., Târgovişte, România.

20. Chirică, V., Bodi, G., 2011, Contribuţii la crearea unui Sistem Informatic Geografic pentru modelarea atlasului arheologic al spaţiului Carpato-Nistrean. Staţiuni paleolitice între Carpaţii Orientali şi Nistru, Bibliotheca Archaeologica Iassiensis XXIV, Institutul de Arheologie - Iaşi, Editura PIM.

21. Ciocârlan, V., 2009, Flora ilustrată a României. Pteridophyta et Spermatophyta, Editura Ceres, Bucureşti.

22. Coldea, G., Cristea, V., Negrean, G., Cristurean, I., Sîrbu, I., Sârbu, A., Oprea, A., Popescu, G., 2003, Ghid pentru identificarea importantelor arii de protecţie şi conservare a plantelor din România, Editura Alo, Bucureşti.

23. Danu, M., Gauthier, E., Weller, O., 2010, Human impact and vegetation history on salt spring exploitation (Halabutoaia - Tolici, Petricani, Neamt, Romania), International Journal of Conservation Science, 1 (3): 167-173.

24. Diaconu, V., 2012, Depresiunea Neamţ. Contribuţii arheologice. Bibliotheca Memoriae Antiquitatis, XXVIII, Muzeul de Istorie şi Arheologie Piatra Neamţ, Editura Constantin Matasă.

25. Djindjian, F., Sapozhnikov, I., Stepanchuk, V., Sapozhnikova, G., 2006, Upper Palaeolithic chronology, cultural facies and economic complexes of the Northern Black Sea area, IV Simposio Cueva de Nerja, La Cuenca Mediterranea Durante El Paleolitico Superior: 46-59.

26. Dobrescu, C., Bârcă, C., Lazăr, M., 1964a, Contribuţii floristice şi geobotanice asupra masivului forestier Bârnova - Repedea Iaşi (I), Analele Ştiinţifice ale Universităţii "Al. I. Cuza" Iaşi, s II Ştiinţe Naturale (Biologie), 10 (1): 147-158.

27. Dobrescu, C., Bârcă, C., Lazăr, M., 1964b, Contribuţii floristice şi geobotanice referitoare la masivul forestier Bârnova - Repedea Iaşi (II), Analele Ştiinţifice ale Universităţii "Al. I. Cuza" Iaşi, s II Ştiinţe Naturale (Biologie), 10 (2): 323-357.

28. Doniţă, N., Popescu, A., Paucă-Comănescu, M., Mihăilescu, S., Biriş, I.A., 2005, Habitatele din România, Editura Tehnică Silvică, Bucureşti.

29. ESRI. ArcGIS Desktop: Release 10. 2011, Redlands, CA: Environmental Systems Research Institute. 


\section{I.A. STOICA, S. FĂRCAŞ, T.M. URSU, B.I. HURDU, P.D. TURTUREANU, M. PUŞCAŞ, A. OPREA, M. PROOROCU}

30. Gafta, D., Mountford, J.M., 2008, Manual de interpretare a habitatelor Natura 2000 din România, Editura Risoprint, Cluj-Napoca.

31. Ifrim, I., Valenciuc, N., 2005, The structure and dynamic of a mixed colony and the microclimate conditions from Grota Mare (Repedea, Iaşi), Studii Cercetări Ştiinţe Biologice Universitatea Bacău, Serie Nouă, 10: 145-150.

32. Kull, T., 1988, Identification of clones in Cypripedium calceolus (Orchidaceae), Proceedings of the Estonian Academy of Sciences, Biology, 37: 195-199.

33. Kull, T., 1999, Cypripedium calceolus L., Biological Flora of The British Isles* No. 208, List Br. Vasc. Pl. (1958) 623, 1, Journal of Ecology, 87: 913-924.

34. Marinescu, Bîlcu, S., Cârciumaru, M., Muraru, A., 1977-1979, Contribuţii la ecologia locuirilor pre- şi protoistorice de la Tîrpeşti, Memoria Antiqvitatis IX-XI, 1985, Acta Musei Petrodavensis - Revista Muzeului de Istorie Piatra-Neamt, 643-684.

35. Mihai, G., Sârbu, I., Horeanu, C., 1973, Flora şi vegetaţia rezervaţiei naturale Dealul Repedea - Iaşi, Studii Comunicări Ocrotirea Naturii, Suceava, 3: 75-87.

36. Mitroescu, S., 1989, Palynological data on the nature reserve "Lunca Zamostei" (Suceava county), Studia Universitatis "Babeş-Bolyai", seria Geologie-Geografie, Cluj-Napoca, XXXIV (2): 95-100.

37. Monah, F., Monah, D., 1997, Stadiul cercetărilor arheobotanice pentru Eneoliticul din Moldova de Vest, Memoria Antiqvitatis XXI, Acta Musei Petrodavensis - Revista Muzeului de Istorie Piatra-Neamt, 297-316.

38. Monah, F., Monah, D., 2003-2004, Les données archéobotaniques du tell chalcolithique de Poduri Dealul Ghindaru, Studii de preistorie, 2, Editura Mica Valahie Bucureşti, 2005, 135-139.

39. Nicoară, M., Bomher, E., 2004, Ghidul Ariilor Protejate din Judeţul Iaşi, S.C. Tipografia Moldova.

40. Nicolè. F., Brzosko. E., Till-Bottraud. I., 2005, Population viability analysis of Cypripedium calceolus in a protected area: longevity, stability and persistence, Journal of Ecology, 93: 716-726.

41. Olaru, L., Schram, M., 1969, Analiza palinologică a sedimentelor lacului Suliţa-Drăcşani (Botoşani), Comunicări de botanică, 10: 17-24.

42. Paavola, J., 2003, Protected areas governance: theory and the European's unions habitats directive, Environmental Science, 1 (1): 59-77.

43. Pop, E., 1929, Analize de polen în turba Carpaților Orientali (Dorna-Lucina), Buletinul Grădinii Botanice și al Muzeului Botanic de la Universitatea din Cluj, 9 (3-4): 81-210.

44. Roman, A., Ursu, T.M., Fărcaş, S., Lăzărescu, V.A., Opreanu, C.H., 2014, Perspectives: Remotely Sensing the Burried Past of Present Vegetation, Proceedings International Workshop Remote Sensing GIS Monitoring Habitat Quality, Vienna, 108-112.

45. Rotar, A., Simon, L., Urdea, P., Voiculescu, M., 2012, A study of institutional stakeholders' views on biodiversity in Romania, Carpathian Journal of Earth and Environmental Sciences, 7 (2): 219 - 230.

46. Sârbu, I., Oprea, A., Lupu, I., 2005, Specii de plante vasculare ameninţate din Moldova. Asociaţia DendroOrnamentală "Anastasie Fătu”, Iaşi, 6-98.

47. Sumares, D., Fidélis, T., 2011, Natura 2000 and the narrative nature of nature: a case for critical discourse analysis, Journal of Integrative Environmental Sciences, 8 (1): 53-68.

48. Terschuren, J., 1999, Action plan for Cypripedium calceolus in Europe, Nature and Environment, no. 100, Council of Europe.

49. ***Assessment, monitoring and reporting under Article 17 of the Habitats Directive - explanatory notes \& guidelines, 2006, European Commission, Brussels.

50. ***Council Directive 92/43/EEC, 1992, on the conservation of natural habitats and of wild fauna and flora. Annex IIb (Animal and plant species of community interest whose conservation requires the designation of special areas of conservation).

51. ***Directive 2009/147/EC (Birds Directive) of The European Parliament and of The Council of 30 November 2009 on the conservation of wild birds (the codified version of Council Directive 79/409/EEC as amended).

52. ***EUR 27/2007, Interpretation Manual of European Union Habitats, European Commission Dg. Environment, Nature and biodiversity.

53. *** GEO 57/2007, regarding the regime of natural protected areas, natural habitats conservation, wild flora 
and fauna, published in the Official Gazette, 442/2007.

54. ***Law no. 5/2000 regarding the approval of the National Spatial Plan - Section III- protected areas, published in the Official Gazette, 152/2000.

55. *** Law no. 49/2011 regarding the approval of GEO 57/2007, published in the Official Gazette, 262/2011.

56. ***OMEF 2387/2011 for the modification of OMMDD 1964/2007 (O.G. 98/2008) regarding the institution of the protected area regime for Sites of Community Importance, as integral part of the European Natura 2000 ecological Network in Romania, published in the Official Gazette, 846/2011.

57. http://ec.europa.eu/environment/nature/natura2000/barometer/index_en.htm

\section{STUDIU DE CAZ ÎN PODIŞUL CENTRAL AL MOLDOVEI, ROMÂNIA - DISTRIBUȚIA HABITATELOR, STAREA DE CONSERVARE ŞI IMPACTUL ANTROPIC DINTR-O ARIE PROTEJATĂ}

\section{(Rezumat)}

Articolul prezintă rezultatele unor studii realizate în situl Natura 2000 Pădurea Bârnova-Repedea, cu scopul de a identifica și carta habitatele și speciile de plante de interes comunitar. Au fost analizate diverse studii palinologice și arheobotanice, pentru a demonstra prezența milenară a pădurilor de foioase în regiune. Această arie protejată a fost desemnată pentru conservarea pădurilor din două habitate de interes comunitar, păduri de fag de tip Asperulo-Fagetum și păduri dacice de stejar și carpen, precum și pentru conservarea unei specii de orhidee periclitată, Cypripedium calceolus L. În timpul studiilor de teren au fost identificate şi alte habitate Natura 2000 de interes comunitar: fânețe montane, stepe ponto-sarmatice și tufărişuri foioase ponto-sarmatice. Informațiile obținute au oferit noi date asupra distribuției habitatelor și speciilor de plante din aria protejată. Datele obținute în teren au fost corelate cu hărțile topografice existente, şi cu fotografii aeriene. Prin folosirea de Sisteme Informatice Geografice, distribuția speciilor şi habitatelor a fost tradusă în hărți precise, ce pot fi utilizate în managementul ariei protejate, pentru implementarea de măsuri conservative adecvate. Activitățile umane cu impact potențial asupra ariei protejate au fost înregistrate. Cu ajutorul acestora, a fost realizată o hartă cu presiunile antropice existente în prezent. 